\title{
Futurism, Henri Bergson and Mina Loy's Female Consciousness
}

\author{
Tan Yujie \\ School of English, University of Leeds, Leeds, UK
}

Email address:

tanyujie19920731@163.com

\section{To cite this article:}

Tan Yujie. Futurism, Henri Bergson and Mina Loy's Female Consciousness. Humanities and Social Sciences. Vol. 4, No. 2, 2016, pp. 46-52. doi: $10.11648 /$ j.hss.20160402.15

Received: February 24, 2016; Accepted: April 9, 2016; Published: April 19, 2016

\begin{abstract}
This paper is concerned with Mina Loy's female consciousness in her poetry between the year of 1914 and 1920 . The first two parts separately discuss how Futurism and Henri Bergson influence Loy. The two influences are concentrated on two different aspects of poems - form and content. Moreover, this paper also finds that the concept of intuition connects Futurism to Henri Bergson in a successive way but inconsistent at the same time. The third part attempts to reveal the controversial points in Loy's female consciousness. The three parts as a unity tend to picture Loy's feminist project.
\end{abstract}

Keywords: Futurism, Henri Bergson, Mina Loy, Poetry, Female Consciousness

\section{Introduction}

Mina Loy's artistic diversity once placed her in an embarrassing position. "It is as though Loy was everywhere but paradoxically nowhere". " She could be visual artist, designer, actor and poet. Carolyn Burke, one of the most influential scholars researching on Loy, specializes in the feature of "modernist". ${ }^{2}$ Burke confirms and reduces the obscurity of Loy's accomplishments achieved in the modern literary history, but Burke is never the only one that admires Loy's extraordinary talent. Megan Harlan notes, "her contemporaries considered Mina Loy to be one of the great Modernist poets, as well as perhaps the first "modern woman"... whose friends and admirers included Gertrude Stein, James Joyce, Djuna Barnes, Man Ray and Marcel Duchamp..." 3 Those contemporaries do credibly prove Loy's identity as an influential modernist. Rachel Blau DuPlessis also comments, Loy "emerges as a key modern writer, one of those we must understand to know the spark of the new." ${ }^{4}$ Loy deserves more attention since she is such an

1 Natalya Lusty, 'Sexing the Manifesto: Mina Loy, Feminism and Futurism', Women: A Cultural Review, Vol. 19.3(2008), p245

2 Carolyn Burke, Becoming Modern: The Life of Mina Loy (Berkeley: University of California Press, 1997)

3 Megan Harlan, 'Becoming Modern', Salon, Vol.9.7(1996),p56

4 Rachel Blau DuPlessis, The Pink Guitar: Writing as Feminist Practice, (Alabama: University Alabama Press, 2006),p109 important and active participator in a variety of modernist movements throughout her whole life, yet she does not gain the recognition as she should. Compared to the contemporaries, she is relatively unknown. Thom Gunn points out the unfamiliarity with Loy, "...there was the legend of her life and the reputation of her poetry, both of them oddly difficult to check up on". ${ }^{5}$ It's Loy's unknownness that requires further exploration.

The existed researches on Loy can not be called immense but rather limited. Burke gives a detailed biography centering around Loy's faithful pursuit for modernity. However, the biography emphasizes a general, macroscopic view of Loy's public and private activities in sequence, thus ignores delicate, close analysis of literary works themselves. There are a few scholars who concentrate exclusively upon Loy's literary accomplishments. They pay their unified interests in Loy's feminist manifesto and its inspiration from Futurism. To be a new woman is related to Loy's childhood memories of her feudal, victorian family and her first disrupted marriage. ${ }^{6}$ Discussing the relationship between man and woman naturally becomes a dominant topic in Loy's works. The timely occurring of Futurism then arms Loy with powerful

\footnotetext{
$5<$ http://www.carolynburke.com/books/reviews/loy_reviews.php\# $>$ [accessed 5 March 2015]

6 Janet Lyon, 'Mina Loy's Pregnant Pauses: the Space of Possibility in the Florence Writings', Mina Loy: Woman and Poet, p391-395
} 
expressions to convey her feminist standing. Julie Schmid discusses Loy's plays writing between 1913 and 1916 on the premise that Loy's contact with Futurism has transformed her into a Futurist. ${ }^{7}$ Loy herself also recognized the "waking me up" effect of Filippo Tommaso Marinetti who is the founder of the Futurist movement. ${ }^{8}$

Modernist movements tend to pride themselves on distinctness, but it does not mean that they are completely isolated from each other. An intelligence intercourse always appears among them. This phenomenon also works on Loy. Loy's gesture of being a new woman is not only inspired by Futurism but also by Henri Bergson. ${ }^{9}$ Meanwhile, it's not a coincidence since Futurism and Henri Bergson share something in common. The meeting of Loy, Futurism, Bergson agrees "the abundance of impulses behind modernism"10.

Based on the discussion above, my study proceeds with the core topic of female consciousness in Loy's works and invites the mechanism of how Futurism and Henri Bergson enlightens Loy. In specific, narrowed to Loy's poems between the year of 1914 and 1920, the development of this study will trace where Mina Loy's female consciousness comes from and how this intellectual realization is settled in poems under certain circumstances. The significance of my study lies in deepening the knowledge of Loy's literary techniques and her avant-garde thoughts. More importantly, Loy is understood in an open, communicative environment. On the one hand, a retrospective view will offer a clearer, fairer way to rediscover Loy's female consciousness. There will be restrictions of the era and illuminations for the present. On the other hand, my study will unfold the inheriting, developing and even betraying among different modernist groups.

\section{Futurism and Mina Loy's Female Consciousness}

Futurism was firstly advertised in public by F.T. Marinetti's Manifesto of Futurism (1909). The manifesto sets the tone of revolution which means discarding things behind the times and seeking for new forms to express modernity. The Futurists are highly sensitive to changes which take place in modern cities and they praise 'the beauty of modern urban life, speed, machinery, violence, youth and expound an aesthetic and ideological programme for the rejuvenation of Italian culture'. ${ }^{11}$ Martin Clark describes Futurists as a group of zealots who worships the Future as the one true God. ${ }^{12}$ The

7 Julie Schmid, 'Mina Loy's Futurist Theater', Performing Arts Journal, Vol.18.1(1996)

8 Virginia M. Kouidis, 'Rediscovering Our Sources: The Poetry of Mina Loy', Journal of Postmodern Literature, Vol. 8.3(1980), pp.167-88.

$9<$ http://modernism.research.yale.edu/wiki/index.php/Mina_Loy\#cite_ref-13 > [accessed 8March 2015]

10 Burke,p166

11 Pierpaolo Antonello \& Marja Härmänmaa, 'Introduction: Future Imperfect-Italian Futurism between Tradition and Modernity', The European Legacy: Toward New Paradigms, Vol.14.7(2009), p777

12 Martin Clark, 'Marinetti and the future perfect', Futures, Vol.10.4(1978),p322
Future can't be doubted or stained. However, Clark doesn't think the God is fair but jealous. For Futurists, the future 'would not allow any other idols from the past to remain standing'. ${ }^{13}$ Clark's analogy reflects the central point in the claims of Futurism - the unconditional and dramatic support for modernity. As implied in "the caffeine of Europe" which contemporaries call Marinetti ${ }^{14}$, Futurism awakens many sleepy minds and creates a passionate, youthful atmosphere. The "caffeine" points to the intensity of influence that suggests the echoic responses stirred in advanced people. Commonly treated as "the first authentic avant-garde movement in Europe", Marinetti's Manifesto of Futurism "inaugurates the heroic years of the so-called 'historical avant-garde",. 15

Since Futurism originally attempts to orientate itself as a global ideology, the avant-garde effect of Futurism covers many art forms. ${ }^{16}$ In terms of poetry, the influence is particularly remarkable. Pierpaolo Antonello \& Marja Härmänmaa notice:

The typographical experimentation of Marinetti's poetry and his "words-in-freedom," for example, had an impact on Russian Futurism (Alexey Kruchenykh, Michail Larionov, David Burliuk), Brazilian Concretism, French Lettrism, and was clearly a precursor of contemporary visual and concrete poetry (Fluxus, e.e. cummings, the Italian Neo-avant-garde, and many others), to say nothing of vast swathes of modern advertising imagery. ${ }^{17}$

Marinetti's radical experimentation with poetry's form reaches far. Form, as a direct expression of movements in mind, can't be expelled from discussions on poetry. Especially for Futurism, form itself is the object to which Futurists tend to make a difference. Technical Manifesto of Futurist Literature (1912) written by Marinetti brings forward specific approaches to Futurist literature. The Manifesto demonstrates the consistency of form with Futurist spirit. Henry Newbolt points:

New feelings necessitate new forms of expression; and as the new feelings are chiefly due to speed, noise, violence, and applied science, the new expression should be appropriately condensed, loud, brutal, wireless, semaphoric, and generally as materialistic as possible. ${ }^{18}$

Technical Manifesto of Futurist Literature is a mirror of Futurist consciousness not only because of the methods it proposes but also the way the manifesto is written. For example, when Marinetti talks about the function of "wireless imagination", he says "it serves to regulate the speed of race of analogies". "19 Vocabulary like "wireless", "speed" is rather Futurist.

\footnotetext{
13 Clark, p323

14 Clark, p322

15 Antonello, p777

16 Luciano De Maria, ' Introduzione in F. T. Marinetti', Teoria e invenzione futurista (Milan: Mondadori, 1968), xix

17 Antonello, p781

18 Henry Newbolt, A New Study of English Poetry(London: Forgotten Books, 2013),p250

19 Newbolt,p248
} 
Mina Loy who was closest to the group of Futurists during 1914 to 1916 willingly accepted these new forms of expression from Futurism. Loy described her appreciation for Futurism's inspiration as being "benefited by a fortnight at the seashore". ${ }^{20}$ Loy began to practice those forward techniques in her poems. In this period, she preferred writing on feminist subjects, which was related to the crisis of her marriage at that time as well as the idea of "new woman" which appeared in the late nineteenth century.

For Loy, testing Futurism's techniques into writing her female consciousness is a reasonable choice. The Futurist spirit behind the expressive form is therapeutic for Loy, liberating her from the psychological predicament. 'Marinetti's 'exuberant personality' and boundless energy during their intermittent wartime affair, and especially his encouragement to dare to be what she wanted" 21 is exactly what Loy needs desperately to help her gain sexual liberty and equality. Therefore, it's wise for Loy to borrow Futurism's literary techniques to voice her feminist request.

To answer how Futurism influenced Loy's writing on her female consciousness, this essay will take the poem Parturition as an example to explore. Mina Loy's Parturition is a feminist poem. It depicts how a woman gives birth. Above all, the subject is feminine enough, exclusive of men. It implies that parturition as a physiological nature determines women's superiority over men. For this reason, parturition acts as a good way to rebuild women's confidence and help them find their irreplaceability in society. The most distinctive feature of giving birth in poem Parturition is feminine subjectivity. Feminine subjectivity has a connection with individual subjectivity defined in medical ethics education. According to Zeng Xuejing, individual subjectivity, including subject consciousness, emotion, will and action, is characterized by "self" serving, independence, activity and creativity. $^{22}$ The concept can be extended to feminine subjectivity in Loy's Parturition. The typical "I am" reflects the center of the woman's sensation:

I am the center

Of a circle of pain

Exceeding its boundaries in every direction

I am the false quantity

In the harmony of physiological potentiality

I am climbing a distorted mountain of agony Incidentally with the exhaustion of control ${ }^{23}$

The feminine subjectivity is characterized by the exclusiveness of men. The exclusiveness in essence is women's consciousness of independence. The independence represents a powerful posture in both physical and mental level.

20 Burke, p156

21 Lucia Re, 'Mina Loy and the Quest for a Futurist Feminist Woman', The European Legacy: Toward New Paradigms, Vol.14.7(2009),p810

22 Xuejing Zeng, 'Emphatically giving to full play subjectivity of the educated in medical ethics education', Journal of China Higher Medical Education, Vol.12.5(2002),p12

23 Conover,p.5
What's the proper way to express the independence in the poem? Mina Loy adopts some of the techniques from Futurism, which could refer to the Technical Manifesto of Futurist Literature(1912) by F.T. Marinetti. One of the example:

Locate an irritation without
It is

Within

It is without

The sensitized area

Is identical with the extensity

Of intension ${ }^{24}$

There is a tanglement among "within" and "without". Mina Loy places these four words in four lines. In each line, she arranges different words and spaces, and even mix a "Within" with upper case letter which is different from other three. Returning to the "without" ends the tanglement. The technique used by Mina Loy in this stanza destroys the harmony and the integrity of the rhythm. The absence of material images further strengthens the feeling of abstractness and uncertainty. Logical sentence structure and conventional grammar disappear and are replaced by isolated words which directly convey the speeding conflict in mind.

Another example is:

Rises from the subconscious

Impression of a cat

With blind kittens

Among her legs

Same undulating life-stir

I am that cat

Rises from the sub-conscious

Impression of small animal carcass

Covered with blue-bottles

-Epicurean-

And through the insects

Waves that same undulation of living

Death

Life

I am knowing

All about

Unfolding 25

The two stanzas above are about the pregnant woman's free imagination. The impressions of the sub-conscious are given through chain of analogies. In Technical Manifesto of Futurist Literature (1912), Marinetti says, "An orchestral style, at once polychromatic, polyphonic, and polymorphous, can embrace the life of matter only by means of the most extensive analogies." 26 The analogies used here succeed in linking the woman's feeling with other forms of life in the universe. Through analogies, maternity is able to communicate with external world, with matter. Analogies expand the feeling of

\footnotetext{
24 Conover,p. 4

25 Conover, p.7

$26<$

http://greeninteger.com/pdfs/marinetti-technical-manifesto-of-futurist-literature.p df $>$ [accessed 28 December 2014]
} 
the woman and make the feeling of the pregnant woman more difficult to understand rather than being simplified.

Writing the process of parturition aims not only at the painful process itself but more at taking it as a medium to advertise women's new minds. In this sense, Futurist techniques arm Loy with power of creativity. In the poem Parturition, the woman who is experiencing the childbirth is actually the narrator. "The sole pre-occupation of the narrator is to render all the shocks and vibrations of his ego." ${ }^{27}$ What the woman attempts to do is to present the mutable ego of herself when she is struggling to give birth to a child. It's evident that Loy tries to prevent maternity from degenerating into a purely physiological passiveness. Parturition is not a compulsory task assigned to women. On the contrary, Loy endows the maternity with highly intellectual initiative. Natalya Lusty summarizes, "The reproductive body is not merely a metaphor for the female poet's creative endeavours, but rather that maternity itself should involve no less of the spiritual and intellectual absorption that pertains to aesthetic creation". ${ }^{28}$ The "aesthetic creation" betraying conventions stands with radical techniques of Futurism.

It can be concluded that techniques borrowed from Futurism represented an innovative power and therefore suited the needs of Loy's poetry as she attempts to write the wakening consciousness of women. Greatly inspired by Futurism, oddness, absurdity, contradiction and fragment are often noticed in Loy's poems. These "aggressive" techniques often cause a dynamic, energetic complexion in her poetry with "blurring of time and space" as well as "interpenetration of mind and body". ${ }^{29}$ At the same time, the unrestrained form itself echoes the free spirit of her female self-consciousness. The unity of form and content contributes a lot to Mina Loy's poems about female consciousness.

Although Loy benefits from Futurism's literary techniques, she is implicated in the potential risk. Marinetti said in Technical Manifesto of Futurist Literature(1912), " It is not necessary to be understood. Moreover we did without it when we were expressing fragments of the Futurist sensibility by means of traditional and intellective syntax. " ${ }^{30}$ Marinetti's indifference to poetry's accessibility results in the tension between him as a poet and readers. Similarly, the "over-experimental" form also brings Loy's poetry with harsh criticism focused on the uncertainty and vagueness of meaning.

In the discussion above, Loy appears to be a faithful follower of Futurism in respect of poetry form. More precisely, she is a passionate, qualified practicer of Futurism's literary techniques. However, faced with Futurism's hegemonic influence, Loy asserts her own autonomy in which subversion can be observed. Her celebration of maternity is adverse to misogyny agreed among Italian Futurism. In Manifesto of Futurism, Marinetti said, "We will glorify war-the world's

\footnotetext{
27 Newbolt, p248

28 Lusty, p255

29 Re,p809

30

$<\mathrm{http} / /$ greeninteger.com/pdfs/marinetti-technical-manifesto-of-futurist-literature. pdf $>$ [accessed 28 December 2014].
}

only hygiene-militarism, patriotism, the destructive gesture of freedom-bringers, beautiful ideas worth dying for, and scorn for woman." 31 It's an irony that Loy borrows techniques from a group who despises femininity. On the other hand, like in the poem Parturition, Loy takes a keen interest in the unconscious domain which Marinetti denies. In Technical Manifesto of Futurist Literature (1912), Marinetti proposed constructing a literary world of matters excluding all psychology of "I". In Parturition, Loy doesn't give up the view of "I" but takes good advantage of the introspection to strengthen the dominance of female consciousness. In this sense, it explains why Loy didn't recognize the title of "Futurist" on her. She is not an absolute Futurist.

\section{Henri Bergson and Mina Loy's Female Consciousness}

Through out the 19th century to the 20th century, Europe experienced an energetic phase fueled by a series of advanced movements in art, philosophy, politics, psychology and so on. Those movements challenged traditional cognition and opened a new outlook. Besides Futurism, Henri Bergson's intuitionism was also one of the representatives. At the same time, Loy was influenced by Bergson as well.

Bergson's intuitionism is firstly established on his theory that regards consciousness or life as the nature and the true reality of the world. The consciousness exists in the world of time. Time is the true duration. Intuition, the only way to the reality, means thinking in duration, in flowing time. In Creative Evolution, Bergson stresses intuition's importance in exploring the inner world:

...it is to the very inwardness of life that intuition leads us-by intuition I mean instinct that has become disinterested, self-conscious, capable of reflecting upon its object and of enlarging it indefinitely. ${ }^{32}$

Moreover, intuition involves a linear perception about time. Bergson believes "Duration is the continuous progress of the past which gnaws into the future and which swells as it advances". ${ }^{33}$ Intuition adopts a dynamic thinking pattern that nothing is stable and predictable.

Bergson's intuitionism influences many great minds at that time including Marinetti and Loy. Marinetti borrows the concept of intuitive from Bergson in his Technical Manifesto of Futurist Literature (1912): "Deep intuitions of life joined to one another, word for word according to their illogical birth, will give us the general lines of an intuitive psychology of matter. This was revealed to me when I was flying in an airplane." ${ }^{34}$ However, there are differences between Henri Bergson's

31 F.T. Marinetti, Selected Writings, ed. R. W. Flint, trans. R. W. Flint and Arthur A. Capotelli (New York: Farrar, Straus and Giroux, 1971), p42

32 Henri Bergson, 'The Divergent Directions of the Evolution of Life -- Torpor, Intelligence, Instinct', Creative Evolution, trans. by Arthur Mitchell, (New York: Henry Holt and Company, 1911),p176

33 Bergson, p4

$34<$

http://greeninteger.com/pdfs/marinetti-technical-manifesto-of-futurist-literature.p df $>$ [accessed 28 December 2014] 
intuition and the intuition used by F.T. Marinetti. The most significant difference lies in the premise. As mentioned in the first part, F.T. Marinetti thinks that the essence of the world is matter and Futurist literature refuses any subjectivity. In contrast, Henri Bergson's intuition regards consciousness as the essence of the world. In other words, Henri Bergson's intuitionism is a theory about the spiritual world while Futurism glorifies the material world. Although the difference mentioned above, both Henri Bergson and F.T. Marinetti treat intuition as a cognitive means that rejects rational analysis.

Bergson's influence on Loy is mainly about the content of poetry. Loy had become familiar with Henri Bergson's intuitionism before she got in touch with the Futurists and she displayed this familiarity in her critical articles. ${ }^{35}$ In this part, this essay will explore how Henri Bergson's intuitionism influences Mina Loy's female consciousness.

In Loy's poems about female consciousness, the concept of intuition defines how the poem proceeds. In other words, the whole poem is a duration of thinking. Take One O'Clock at Night from Three Moments in Paris as an example.

The poem overall describes the process of a woman going from " being asleep " to "being awake". It's also a process of how the consciousness revives. The transition is:

Deafening woke me

And I caught the thread of the argument

Immediately assuming my mental attitude

And ceased to be a woman 36

Followed is the speaker's thinking as a response to what men has said:

Beautiful half-hour of being a mere woman

The animal woman

Understanding nothing of man

But mastery and the security of imparted physical heat

Indifferent to cerebral gymnastics

Or regarding them as the self-indulgent play of children

Or the thunder of alien gods

But you woke me up ${ }^{37}$

" The animal woman " here is different from the image in previous stanzas which is obsessed with the male voice. " The animal woman " is not a fighter against men either. "The animal woman " is a device used by Loy to make the distinctions between men and women more vague. This means encouraging women to discard taking men as measures. Women should regard men as children fooling around rather than competitive enemies. Women need to place themselves in the central place rather than attach themselves to men. This viewpoint is in accordance with " nothing impure in sex " proposed in Feminist Manifesto.

The duration of thinking occupies the whole poem even in the woman's sleepy time. Loy writes:

And the only less male voice of your brother

pugilist of the intellect

\footnotetext{
35 Kouidis,p. 174

36 Conover, p. 15

37 Conover, p. 15
}

Boomed as it seemed to me so sleepy ${ }^{38}$

This fragment implies the woman's judgment of masculinity in dazed condition. The word " less " confirms the comparison in the mind of the speaker. Being sleepy is a façade for surveying men's talk while keeping a safe distance. Therefore, " ceased to be a woman " 39 is an intentional choice. The movement of consciousness never stops.

In another poem There is no Life or Death, the inner experience of the speaker also coincides with the intuitive ways of understanding. Loy writes:

There is no Life or Death,

Only activity

And in the absolute

Is no declivity

There is no Love or Lust

Only propensity

Who would possess

Is a nonentity.

There is no First or Last

Only equality

And who would rule

Joins the majority.

There is no Space or Time

Only intensity,

And tame things

Have no immensity. ${ }^{40}$

There are four sections. Each section shares the same grammar without unexpected points. The core idea in this poem agrees with the intuitive ways of understanding. The spirit can enter the inside of the object with the effort of the will and mingle with its nature.

Every current conscious state contains all of the past ones and indicates the formation of a new one. Without any transition, every state would stretch to and permeate other states. Psychological flow is constant and it stretches towards various directions. This philosophical perspective inspires readers to penetrate into the speaker's inner world and pay attention to their psychological changes. This includes understanding the source and destination of the speaker's psychological state, observing psychological changes in a continuous process and finding out what factors rise or decline. For example, how the speaker in One O'Clock at Night expresses her feminist standing step by step. The argument between the two men presents the temporal situation that is male dominated. After weighing this circumstance, the woman chooses to be "the animal woman". "The animal woman" is an instant response behind that there is a running thinking process. To conclude, Henri Bergson's intuitionism provides an opportunity to deeply explore Mina Loy's female consciousness in duration.

Since intuition is a non-conceptual and non-analytic way of understanding, a certain degree of rationality is necessary to coordinate the intuitional realization. Intuition and rationality

\footnotetext{
38 Conover, p.15.

39 Conover, p. 15.

40 Conover, p.3.
} 
is not absolutely contradictive. To gain a balance between the two, intelligence can't be sent away. Bergson explains: "Intuition introduces us into life's own domain, which is reciprocal interpenetration, endlessly continued creation. But, though it thereby transcends intelligence, it is from intelligence that has come the push that has made it rise to the point it has reached." 41

\section{Controversial Moments in Mina Loy's Female Consciousness}

Following the discussion above, I will then push my study of Loy's female consciousness into a critical stage. Mina Loy's female consciousness is systematically presented in her Feminist Manifesto (1914). Loy emphasized female's independence from different aspects. Marriage is not a must for a woman to be a mother but being mentally mature. At the same time, Loy thinks that marriage should not be a business of exchanging women's virginity for guaranteed wealth. She insists that women must have their own career and achieve their own value. The strongest voice is Loy's standing on the matter of sex. She writes that there is nothing impure in sex. She means that there is no need for women to be bothered by virginity and women deserves to enjoy sex. ${ }^{42}$

Although Loy's female consciousness favors enlightening and unchaining the old minds of women, there are several paradoxical points in the manifesto. One paradox lies in women's responsibility for the family. Mina Loy said, " Woman must become more responsible for the child than man. ${ }^{43}$ If this conclusion is true, the traditional family roles must be guaranteed. Men go to work and women run the household. However, Mina Loy maintains that women must have a job to feed themselves and stop exchanging sexual relationship for wealth. There exists an apparent contradiction in logic. For the former, women stay at home. For the latter, it implies that women should leave home to find a job.

The contradiction mentioned above is similar to another one in Hélène Cixous's feminine writing. ${ }^{44}$ Cixous claims the feminine writing as women's privilege. However, in other place, she writes that both men and women could write ecriture feminine. ${ }^{45}$ For both Loy and Cixous, the paradox in their writing is a mirror of uncertainty in mind. Different to Cixous who advocates writing in a feminine way, Loy's style is more innovative and aggressive even when she talks about a theme like parturition. In poem Parturition, non-feminine images like cosmos and carcass are scattered everywhere. This preference highlights Loy's idiosyncratic posture as a feminist. In Feminist Manifesto, Loy writes, "Women must destroy in themselves, the desire to be loved. " ${ }^{46}$ She means

\footnotetext{
41 Bergson, p178

42 Conover,p153

43 Conover, $\mathrm{p} 155$

44 Vincent B., Leitch, ed., 'Feminism, Hélène Cixous ', in The Norton Anthology of Theory and Criticism (New York: W. W. Norton \& Company, 2001), p.2035.

45 Leitch, p. 2036.

46 Conover, p. 155
}

that femininity is not inherent for women. Loy advises a reconstruction of internal-independent femininity and she disagrees with the concept of female that is defined in the comparison with male.

What's more, the feasibility of the manifesto is closely related to the social background at that time. Since freedom and equality for women can't live without financial security, it's vital for Mina Loy to encourage women to refuse gaining money from marriage. However, before the World War One, a very small number of jobs were available to women. The wakening in consciousness is not enough for independence. After the World War Two, especially in post-industrial age, Loy's proposal grows more realistic with more jobs suitable for women.

\section{Conclusion}

Mina Loy's female consciousness concentrates on women's independence of mind and body. The concept of independence is exclusive of men and abandons treating men as enemies. In the early twentieth century, Mina Loy's opinions are advanced. However, at the same time, her opinions are also restricted by the era. The social background at that time is not mature enough for women to realize their independence.

How Mina Loy writes her female consciousness is greatly inspired by both Futurism and Henri Bergson's intuitionism. Mina Loy adopts experimental techniques from the former and takes the latter philosophy as the way of thinking while writing poetry. Despite the negative aspects, the two indeed help Mina Loy's feminist voice stand out.

\section{References}

[1] Antonello, Pierpaolo \& Härmänmaa, Marja, 'Introduction: Future Imperfect-Italian Futurism between Tradition and Modernity', The European Legacy: Toward New Paradigms, Vol. 14. 7(2009), p 777-84

[2] Bergson, Henri, 'The Divergent Directions of the Evolution of Life -- Torpor, Intelligence, Instinct', Creative Evolution, trans. by Arthur Mitchell, (New York: Henry Holt and Company, 1911)

[3] Bloom Harold, The Art of Reading Poetry (New York: Harper Perennial, 2005)

[4] Burke, Carolyn. Becoming Modern: The Life of Mina Loy (New York: Farrar, Straus, and Giroux, 1996)

[5] Clark, Martin, 'Marinetti and the future perfect', Futures, Vol. 10. 4 (1978), p322-26

[6] DuPlessis, Rachel Blau,, The Pink Guitar: Writing as Feminist Practice, (Alabama: University Alabama Press, 2006), p109

[7] Harlan, Megan, 'Becoming Modern', Salon, Vol. 9.7 (1996), p56

[8] Kouidis, Virginia M., 'Rediscovering Our Sources: The Poetry of Mina Loy', Boundary2: A Journal of Postmodern Literature, Vol. 8, No. 3 (1980), p167-88 
[9] Leitch, Vincent B, ed., 'Feminism, Hélène Cixous', in The Norton Anthology of Theory and Criticism (New York: W. W. Norton \& Company, 2001)

[10] Loy, Mina, the Lost Lunar Baedeker Poems, ed. Roger L. Conover (Manchester: Carcanet Press, 1997)

[11] Lusty, Natalya, 'Sexing the Manifesto: Mina Loy, Feminism and Futurism', Women: A Cultural Review, Vol. 19. 3(2008), p 245-60

[12] Lyon, Janet, 'Mina Loy's Pregnant Pauses: the Space of Possibility in the Florence Writings', Mina Loy: Woman and Poet, p 391-395

[13] Maria, De, Luciano, 'Introduzione in F. T. Marinetti', Teoria e invenzione futurista (Milan: Mondadori, 1968)

[14] Marinetti, F. T., Selected Writings, ed. R. W. Flint, trans. R. W. Flint and Arthur A. Capotelli (New York: Farrar, Straus and Giroux, 1971)
[15] Marianne Martin, Futurist Art and Theory (Oxford: Oxford University Press, 1968)

[16] Newbolt, Henry, A New Study of English Poetry (London: Forgotten Books, 2013)

[17] Re, Lucia, 'Mina Loy and the Quest for a Futurist Feminist Woman', The European Legacy: Toward New Paradigms, Vol 14. 7(2009), p799-819

[18] Schmid, Julie, 'Mina Loy's Futurist Theater', Performing Arts Journal, Vol. 18. 1(1996), p 1-7

[19] Shreiber, Maeera and Keith Tuma, ed. Mina Loy: Woman and Poet (Orono ME: National Poetry Foundation, 1998)

[20] Zeng, Xuejing, 'Emphatically giving to full play subjectivity of the educated in medical ethics education', Journal of China Higher Medical Education, No. 5 (2002), p 12 